\title{
PALANKIOS STUDIJŲ APLINKOS POREIKIS: Z KARTOS ATVEJIS
}

\author{
Doc. dr. Jūratė Guščinskienė \\ Aušra Kaminskaitè \\ Generolo Jono Žemaičio Lietuvos karo akademija
}

\begin{abstract}
Anotacija. Publikacijoje atkreiptas dèmesys $\underset{\text { }}{ } X X$ amžiaus pradžioje atsiradusia „,naujaja “ aukštojo mokslo paradigma, remiantis kuria turejo išaugti studento / besimokančiojo vaidmuo mokymo procese. Ši paradigma buvo išplètota XXI amžiuje remiantis Bolonijos procesu, ypač Leveno ir naujojo Luveno komunikatuose (2009). Pagal šia paradigma Europos mokslo erdveje studiju programu tikslas turi büti i studenta orientuotas mokymas. Straipsnyje nuosekliai aptartos $i$ studenta orientuotos studijos; desstytoju ir studentu tarpusavio santykiai ir vaidmenys mokymo procese; studiju aplinkos: infrastruktūra ir mokymosi erdvès; pristatoma šiuo metu aukštosiose mokyklose besimokanti Z karta ir aptariami 2018 metais publikacijos autoriu atlikto originalaus empirinio tyrimo rezultatai.
\end{abstract}

Pagrindiniai žodžiai: Z karta, i studenta orientuotas mokymas, lūkesčiai, vertybès, individualus darbas ir darbas grupèse, mokymo metodai.

\section{Ivadas}

XX a. pabaigoje - XXI a. pradžioje įvyko realus universitetinio mokslo paradigmų virsmas, dèl ko pagrindinis dèmesys buvo nukeiptas nuo dèstytojo ị studentą. İ studentą orientuotos studijos remiasi keliais principais (Guščinskienė, Čiburienè, 2018): mokymas reikalauja nuolatinès refleksijos; nesilaikoma visiems vienodai tinkamo mokymo metodo, todèl besimokantieji mokosi skirtingai; studentai turi individualius ir neretai skirtingus poreikius ir interesus; studiju procese atsiranda pasirinkimo galimybé; orientuojamasi ị skirtingas studentų žinias; besimokantieji turi patys kontroliuoti savo mokymąsi; studentų igalinimas mokymosi procese (ne žinių / informacijos atkartojimas); studento ir administracijos bendradarbiavimas.

Kiekviena karta yra savita, turi skirtingas vertybes, lūkesčius, nevienodai mąsto ir priima sprendimus, skirtingai mokosi, todèl skirtingų kartų akademiniai poreikiai kinta. Z kartos atstovų socialinių medijų ir išmaniujų technologijų vartojimo ịūdžiai yra kur kas geresni nei ankstesnių kartų. Jie siekia savo hobị paversti pagrindiniu pragyvenimo šaltiniu, labiausiai vertina asmeninę, o ne autoritetu grịstą patirti, todèl siekia viską patirti patys. Jie domisi verslo vadybos, psichologijos, 
švietimo, sistemų plètros, mokymų ir vystymo studijomis, tačiau savo išsilavinimo ambicijas apriboja bakalauro studijomis.

Nemažai užsienio ir Lietuvos autorių analizavo ị studentą orientuotų studijų ir Z kartos problematiką. Jų darbai aptarti kituose šio straipsnio skyriuose.

Tyrimo problema. Nors universitetinio mokslo paradigma patiria nuolatinę dinamiką, tačiau Z karta kelia išskirtinius poreikius palankiai aplinkai aukštajame moksle.

Tyrimo objektas. Z kartos požiūris ị studijų aplinką aukštojoje mokykloje.

Tyrimo tikslas. Konceptualizavus ị studentą orientuotas studijas ir remiantis 2018 m. gruodžio mèn. atlikto tyrimo rezultatais aptarti konkrečius $\mathrm{Z}$ kartos studentų poreikius ir jų nuomonę apie studijų aplinką.

Tyrimo uždaviniai: 1) išnagrinèjus mokslinę literatūrą išsiaiškinti dèstytojų ir studentų tarpusavio santykius ir vaidmenis mokymo procese; 2) atlikti studiju aplinkos teorinę analizę; 3) aptarti Z kartos bruožus ir išnagrinèti poreikius; 4) pristatyti Z kartos studentų nuomonę apie universitetinių studijų aplinką.

Tyrimo metodai. Mokslinès literatūros turinio analizè, pusiau struktūruotas interviu, sisteminimas, interpretacija.

\section{I studentą orientuotos studijos}

Pagal „senaja“ aukštojo (universitetinio) mokslo paradigmą, studijų proceso centre buvo dèstytojas, turintis reikiamų žinių, patyrimą, sprendžiantis kada, ką ir kaip dèstyti, tuo tarpu studentų, absolventų ir darbdavių vaidmuo šiame procese buvo minimalus. Manoma, kad tokie studijų metodai neskatino besimokančiuju aktyvumo, kūrybingumo, o žinias studentai neretai ịsimindavo gana paviršutiniškai, ne visada suprasdami jų pridedamają vertę ateityje. Pirmą kartą ị ,studentą orientuoto mokymo" sąvoką 1905 m. pristatė Hayward, o 1956 m. ją aptarẻ Dewey (Baužienè, Daniels ir kt., 2018).

XX amžiaus pradžioje užgimusi „nauja“ aukštojo mokslo paradigma, remiantis kuria turejo išaugti studento / besimokančiojo vaidmuo, buvo išplètota XXI amžiuje remiantis Bolonijos procesu, ypač Leveno ir naujojo Luveno komunikate (2009), nurodančiame, kad Europos mokslo erdvejje studijų programų tikslas turi būti ị studentą orientuotas mokymas. Nemažai užsienio šalių tyrinètojų analizuoja į studentą orientuotų studijų tematiką, pavyzdžiui, J. Cox (2011) ir G. Galilei (2016) analizavo ị studentą orientuotų studijų paradigmą ir sampratą, R. Robinson ir J. Reinhart (2014) tyrinejjo šiuolaikinių technologijų naudojimą studijų procese, B. Loveless (2019 ), M. Weimer (2013), M. Powel (2014), M. B. Gilboy, S. Heinerichs ir G. Pazzaglia (2015) aptaré auditorijų pritaikymą studijų procesui ị studentus orientuotų studijų atveju, O. Nessipbayeva ir R. Egger (2015) tyrè nūdienos aukštosios mokyklos infrastruktūrą ir kt. Lietuvoje ị studentą orientuotų studijų paradigmą, aptariant jos etapus, principus, naudą asmeniui ir visuomenei, randame L. Sajienès ir R. Tamulienès (2012), K. Peilakauskaitès ir A. Varanausko (2011), J. Guščinskienès, J. Čiburienès (2018) ir kituose darbuose. 
J. Cox (2011) suformulavo ị studentą orientuoto aukštojo mokslo paradigmą, pateikè i studentą orientuoto mokymo apibrèžimą ir jo komentarą: ,I studenta orientuotas mokymas reiškia pagalba studentams atrasti savo mokymosi stiliu, suvokti savo motyvacija bei igyti efektyviu mokymosi igūdžiu, kurie pravers visa gyvenima. " Perkèlus ši požiūrị i praktika, tai reikštu, jog dèstytojai turi padèti studentams nusistatyti pasiekiamus tikslus; skatinti studentus vertinti save ir kolegas; padèti jiems dirbti kartu grupèse ir užtikrinti, jog jie žino, kaip panaudoti visus prieinamus mokymosi išteklius. Taigi mokymasis labiau yra asmeninio tobulejimo forma, o ne linijine progresija, kuria mokytojas pasiekia paskatinimais ir sankcijomis" (Cox, 2011).

Dėstytojų ir studentų tarpusavio santykių ir vaidmenų kaita mokymo procese

Studiju procese dalyvauja trys tarpusavyje susiję subjektai: studentai, dėstytojai ir administracija. I̦ studentą orientuotas mokymas remiasi keliais pagrindiniais principais:

1) studentas pats atsakingas už savo mokymąsi, jis aktyviai dalyvauja tobulindamas ir keisdamas save;

2) mokymas reikalauja nuolatinès refleksijos;

3) nesilaikoma visiems vienodai tinkamo mokymo metodo, todèl besimokantieji mokosi skirtingai;

4) studentai turi individualius ir neretai skirtingus poreikius bei interesus;

5) studijų procese atsiranda pasirinkimo galimybė;

6) aktyvių mokymo metodų taikymas;

7) orientuojamasi ị skirtingas studentų žinias;

8) besimokantieji turi patys kontroliuoti savo mokymąsi;

9) studentų igalinimas mokymosi procese (o ne tik žinių / informacijos atkartojimas);

10) studento ir dėstytojo, studento ir administracijos bendradarbiavimas.

I dèstytoją ir ị studentą orientuotas studijas palygino ir esminius skirtumus išryškino G. O’Neill ir T. McMahon (2005). Studijų lyginimas pateiktas 1 lentelèje.

\section{1 lentelè. İ dèstytoją ir ị studentą orientuotų studijų lyginimas}

\begin{tabular}{|l|l|}
\hline \multicolumn{1}{|c|}{ I dėstytoją orientuotos studijos } & \multicolumn{1}{c|}{ I studentą orientuotos studijos } \\
\hline $\begin{array}{l}\text { — Pagrindinis veikèjas mokymo procese yra } \\
\text { déstytojas }\end{array}$ & • Pagrindinis veikėjas mokymo procese yra \\
- Menka galimybè studentui rinktis & studentas \\
- Studentai pasyvūs & • Aukštas studentų pasirinkimo lygis \\
\hline
\end{tabular}

Sudaryta pagal O’Neill, McMahon, 2005, p. 32. 
E. Leibtag (2017) išskiria kelis esminius dalykus, svarbius ị studentą orientuotose studijose (Liebtag, 2017):

1) aukštas studentų dalyvavimo lygis (paskaitų ir popaskaitineje veikloje, mokslinių draugijų veikloje ir kt.);

2) studentų žinojimas, ką ir kodèl jie mokosi (studentai motyvuoti, domisi būsimomis darbo perspektyvomis, planuoja mokytis visą gyvenimą ir kt.);

3) asmeninė ir komandinè grupès veikla atliekant užduotis (studentams sudaromos sąlygos pasireikšti asmeniškai, komandos ar grupès lygmeniu, jiems suteikiama galimybè rinktis);

4) studentų individualizuotų technologijų naudojimas (skaitmeninių technologijų svarba ypač didejja ir jas studentai naudoja ne tik kaip vartotojai, bet ir kaip kūrejjai);

5) studentų darbas individualia sparta (studentams užduotys paruošiamos atsižvelgiant į jų mokymosi spartą ir jų interesus, turimas žinias ir ịgytus įgūdžius);

6) aktyvus studentų dalyvavimas studijų procese diskutuojant, analizuojant ir pan. (studentai dalyvauja tobulindami studijų dalykų dėstymą, rinkdamiesi mokymo šaltinius ir mokymo metodus bei kt.);

7) grį̌tamojo ryšio užtikrinamas (studentai dalyvauja studijų programų, atskirų dėstomųjų dalykų vertinimo procesuose ir kt.);

8) mokymas, organizacinè kultūra atspindi ir apima studentų bei darbuotojų įvairovę.

I studentą orientuotų studijų procese kinta mokymo metodai. G. O’Neill ir T. McMahon (2005) savo darbe dėstytojų taikomus mokymo metodus sugrupavo $\mathfrak{i}$ tuos metodus, kuriuos dèstytojai taiko paskaitų ir pratybų metu bei popaskaitiniu laiku (̌̌r. 2 lentelę).

2 lentelè. İ studentą orientuotų studijų mokymo metodų pavyzdžiai

\begin{tabular}{|c|c|}
\hline Paskaitų ir pratybų metodai & Popaskaitiniai metodai \\
\hline Trumpos diskusijos poromis & Individualūs projektai \\
\hline Didesnių grupių, sudarytų sniego gniūžtės principu, diskusijos & Grupinės diskusijos \\
\hline $\begin{array}{c}\text { Grupių sudarymas pagal studentų numerius } \\
\text { (studentų sumaišymas) }\end{array}$ & Kitų studentų konsultavimas \\
\hline Raundai (individualios studentų kalbos) & Debatai \\
\hline Viktorinos & Mokomosios išvykos \\
\hline Refleksijų rašymas & Praktikos \\
\hline Studentų prezentacijos auditorijai & $\begin{array}{c}\text { Dienoraščių rašymas, } \\
\text { mokymosi žurnalai }\end{array}$ \\
\hline Vaidmenų žaidimai & \begin{tabular}{c} 
Mokymasis su kompiuteriu \\
\hline Plakatų (angl. poster) pristatymai
\end{tabular} \\
\hline Minčių žemèlapių kūrimas auditorijoje & $\begin{array}{c}\text { Studijų dalykų / } \\
\text { projektų pasirinkimas }\end{array}$ \\
\hline
\end{tabular}

Sudaryta pagal O’Neill, McMahon, 2005, p. 34. 


\section{Studijų aplinkos: infrastruktūra ir mokymosi erdvès}

Viena pagrindinių sèkmingo mokymosi sąlygų šiandieninèje aukštojoje mokykloje - yra mokymosi aplinkos, kuriose studentui suteikiamos galimybės gauti studijų procesui reikalingą ir jam įdomią bei aktualią informaciją (formaliajam ir neformaliajam mokymuisi), kur jis gali pasidalyti savo patirtimis su bendramoksliais ir dèstytojais, kur jis jaučiasi saugus ir gali mokytis pagal savo individualią darbo spartą ir ritmą.

Nemažai tyrëjų, analizuojančių i studentus orientuotas studijas, sukoncentruoja savo dèmesi i i aukštosios mokyklos infrastruktūrą ir jos aprūpinimą šiuolaikinėmis technologijomis. Pavyzdžiui, aukštosios mokyklos įvairių mokymosi aplinkų įvairovę, poreikị ir svarbą, taip pat skaitmeninių technologijų pritaikymą studiju procese analizuoja R. Robinson ir J. Reinhart (2014), O. Nessipbayeva ir R. Egger (2015) tyrinejja aukštosios mokyklos infrastruktūrą ir atlieka skirtingu šalių infrastruktūrų lyginamają analizę, B. Loveless (2019), M. Weimer (2013) ir M. Powel (2014) aptaria, kaip turètų atrodyti šiuolaikinè auditorija su integruotomis technologijomis, skirta ị studentus orientuotoms studijoms ir kt. Didžiausias šiandieninès auditorijos skirtumas nuo tos, kuri buvo daugiau nei prieš šimtą metų, tai - išmaniosios auditorijos, turinčios projekcines sistemas, kompiuterius, vaizdo ir garso įrašų ịrangą, ịvairias programas ir kt., t. y. visa tai, kas yra būtina studijų, orientuotų ị studentą, procese.

XXI amžiaus aukštojoje mokykloje mokymas ir mokymasis yra kompleksinis. Dėstytojas yra mokymo proceso mentorius. Mokymo proceso sėkmei ypač svarbios mokymosi erdvès. Mokymosi erdvè gali būti apibūdinta kaip bet kokia vieta, kurioje vyksta mokymasis (Robinson, Reinhart, 2014, p. 59). Šios erdvès gali būti:

- formalios fizinès vietos, pavyzdžiui, auditorijos ir konferencijų salès;

- neformalios, tokios kaip bibliotekos, kavinès ir studijoms skirti kambariai;

- virtualios, pavyzdžiui, dèstytojo vadovaujama diskusijų erdvé / terpé, skirta pasikeitimui informacija studijų programos tema, kurioje gali bendrauti dèstytojas ir studentai ir (arba) studentai tarpusavyje.

Šiuolaikinès technologijos labai pakeitè mokymosi erdvių kūrimo būdą. Aukštosios mokyklos studijoms skirtos erdvès, siekiant studijas orientuoti ị studentą, gali būti ịvairios priklausomai nuo mokymo formos, užsièmimų ir darbo / studijų pobūdžio, atitinkančio studentų ir dẻstytojų ịvairovę bei jų poreikius ir pan. Minètos erdvès gali būti skirtos (Robinson, Reinhart, 2014, p. 58-60):

- paskaitoms;

- darbui mažomis grupèmis;

- darbui poromis;

- individualiam darbui.

Auditorijos fizinè erdvė turi būti orientuota ị studentą. Toje aplinkoje turètų būti patogu naudoti šiuolaikines technologijas, kurių taikymas turètų derèti su studijų programa. Studentai aukštojoje mokykloje turètų turèti galimybę naudotis vir- 
tualia erdve ne tik per paskaitas, bet ir popaskaitiniu laiku bei taikyti ją formaliajam ir neformaliajam mokymuisi.

\section{Z kartos bruožai ir poreikiai}

Amžiaus grupè, arba karta, kaip socialinis demografinis indikatorius dažnai taikomas visuomenès tyrimuose. M. Rokeach ir kiti mokslininkai atliktuose tyrimuose (Robbins, 2007) pastebèjo, kad amžiaus grupè, pavyzdžiui, darbo jègos kohorta, turi panašias vertybes, lūkesčius ir demonstruoja panašią elgseną.

Baigiantis antrajam XXI a. dešimtmečiui universitetų auditorijas užpilde studentai, priklausantys vadinamajai Z kartai. Ivairūs autoriai skirtingai nurodo šios kartos ribinį gimimo laiką, tuo pačiu įnešdami painiavos tarp $\mathrm{Z}, \mathrm{Y}$ ir vadinamosios tūkstantmečio (Millennias) kartos. Taip pat pastebima, kad geografinè, ekonominè ir kultūrinè konkrečios šalies aplinka turi ịtakos nustatant, kuri karta šiuo metu vyrauja tarp studentų. Lietuvos mokslininkiu grupè V. Targamadzè, S. Girdzijauskienè, A. Šimelionienè ir kt. (2015), remdamosi sociologais A. McCrindle ir N. H. Wolfinger (2010), savo mokslo studijoje bene išsamiausiai aptarè Z kartą jos moksleiviškais metais. Grupe teigia, kad Z kartai priklauso žmonès, gimęs tarp 1995-2012 metų. Tam pritaria M. Kleinschmit (2019), E. Jeleniauskienè ir P. Jucevičienè (2015). Tuo tarpu S. Ramoškienė (2014) teigia, kad Z kartai priklauso žmonès, gimę tarp 2003-2023 metų. Šio darbo autorès laikosi nuomonès, kad dabar Lietuvos universitetuose studijuoja „zetai“, kitaip sakant, $\mathrm{Z}$ kartos jaunuoliai.

Kiekviena karta yra savita, turi skirtingas vertybes, lūkesčius, skirtingai mąsto ir priima sprendimus, skirtingai perka ir valgo, skirtingai mokosi ir netgi rengiasi, teigia S. Ramoškienè (2014). Apibūdinant $\mathrm{Z}$ kartą, iš karto krinta į akis tai, kad jų socialinių medijų ir išmaniujų technologijų naudojimo ịūdžiai yra kur kas geresni nei ankstesnių kartų. Nuo ankstesnių kartų „zetai“ ypač išsiskiria tuo, kokius konkrečius socialinius tinklus jie lanko, kuriuos mobiliuosius ir išmaniuosius įrenginius jie naudoja ir (ar) žiūri televiziją. Kaip teigia M. Kleinschmit (2019), atlikęs keletą $\mathrm{Z}$ kartos tyrimų JAV, šiems jaunuoliams tarp visų technologinių ịrenginių būtent išmanieji telefonai yra reikalingiausi ir dažniausiai naudojami, ten jie randa viską, kas juos domina. Nurodoma, kad išmaniaisiais telefonais jie vidutiniškai naudojasi 15,4 val./sav. Palyginimui, televizorių žiūri (13,2 val./sav.) ar dirba su nešiojamuoju kompiuteriu (10,6 val./sav.). Ne veltui šios kartos moto (šūkis) yra: „Mes esame visada prisijungę, bet kur ir bet kada, esame visada pasiekiami“. Siekiant pažinti ir pasiekti šią jaunuolių grupę, būtina žinoti ne tik tai, kad jie virtuoziškai naudojasi išmaniosiomis technologijomis, bet ir susipažinti su jiems įdomiausiais socialiniais tinklais ir kanalais. Pagal populiarumą pastarieji išsidėsto šitaip: Snapchat, Instagram, Youtube. Tuo tarpu Facebook, Twitter, Linkedln ,zetams“ yra mažiau įdomūs.

Apskritai ši karta turi puikius technologinius igūdžius, jiems būdingas technologinis virtuoziškumas, internetiniai (angl. online ) tyrimai, verslumas ir inovatyvu- 
mas. Teigiama, kad jie yra iš prigimties verslininkai, karjeristai, aktyvistai ir agitatoriai, dideli svajotojai ir vizionieriai. M. Kleinschmit (2019) juos vadina pointernetine karta, nes ši karta ne tik naudojasi internetu, bet ir kuria jo produktus, pramogas ir pastarąsias tobulina. Be to, septyniasdešimt penki procentai $\mathrm{Z}$ kartos atstovų siekia savo hobi paversti pagrindiniu pragyvenimo šaltiniu. Jie domisi verslo vadybos, psichologijos, švietimo, sistemų plètros, mokymų ir vystymo studijomis, tačiau savo išsilavinimo ambicijas apriboja bakalauro studijomis, kurių trukmè nuo trejų iki ketverių metų. $\mathrm{Z}$ kartos jaunuoliai labiausiai vertina asmeninę, o ne autoritetų grịsta patirti, todèl siekia viską patirti patys, nors vertina ir nenutrūkstamą dialogą. Jie yra nenuoramos, nenustygstantys ramiai vienoje vietoje. Jie siekia būti populiarūs ir madingi, nors tiek daiktais, tiek savo elgsena nebūtinai išsiskiria ir (ar) yra unikalūs.

V. Targamadzè, S. Girdzijauskienè, A. Šimelionienè ir kt. (2015) tyrinèdamos Z kartą mokykloje ją įvardijo kaip ,skaitmeninę", ,virtualios aplinkos “, „, skaitmenines kartos čiabuviais “. Z karta yra įnikusi ị virtualią realybę, kur gauna visą informaciją, taip bandydami suprasti ir išspręsti visas iškylančias problemas. Pasaulis jiems skaidosi ị dvi dalis - virtualų ir realų, ir jie dažnai painioja virtualią ir realią aplinką. Jiems virtuali erdvė tampa gyvenimo ir buvimo vieta. Pasaulio suvokimas vyksta per kompiuterinius žaidimus, todẻl tradicinį bendravimą pakeičia netiesioginis, o virtualusis. Bendraujama daugiausiai socialiniuose tinkluose. Virtualus pasaulis jiems atrodo realesnis už tikrajį. Virtualioje erdvèje jie jaučiasi saugesni ir savarankiškesni. Z kartos lūkesčiai skiriasi nuo kitų kartų, o sprendimų prièmimui didžiausią ịtaką daro draugų nuomonė ir informacija, rasta internete. V. Targamadzè, S. Girdzijauskienè, A. Šimelionienè ir kt. (2015) taip pat atkreipia dèmesi, kad Z karta labai tiki tuo, kas parašyta internete, ir dažnai negeba atsirinkti patikimų šaltinių. Taigi, internetas, globali aplinka turi dideli poveikị ir Z kartos vertybių formavimuisi. Jie yra linkę priešintis nustatytoms normoms, yra priklausomi nuo technologijų ir neretai yra hiperaktyvūs. Be to, jie yra individualistai ir nori dirbti tik su tais žmonėmis / kolegomis, kurie jiems patinka, ir užsiimti tik tokia veikla, kuri juos domina. Kita vertus, jie yra gana komunikabilūs ir socialiniuose tinkluose turi daugybę draugų, su kuriais dažnai bendrauja ir užsienio kalbomis.

Šiuo metu dalis $Z$ kartos atstovų ne tik studijuoja, bet yra pradejję savo darbinę karjerą. S. Ramoškienè (2014) teigia, kad Z kartos darbuotojai nemėgsta fizinio darbo. Jie nori mažiausiomis sąnaudomis užsidirbti maksimalų atlyginimą, netgi turèdami visiškai menkus gebejimus ir neturèdami pakankamai patirties. Jie linkę labiau dirbti individualiai, nei ịsilieti ị kolektyvą, pageidauja lankstaus darbo grafiko ir (ar) net darbo neišeinant iš namų.

\section{Z kartos studentų nuomonė apie universitetinių studijų aplinką}

2018 metų gruodžio mėnesį Kauno technologijos universiteto Socialinių, humanitarinių mokslų ir menų fakultete egzaminų sesijos metu buvo atliktas bandomasis kokybinis tyrimas. Tyrimo metu buvo apklausti fakulteto bakalauro studiju 
studentai. Taikant pusiau struktūruotą interviu metodą buvo siekiama išsiaiškinti konkrečius Z kartos studentų poreikius universitete, sužinoti jų nuomonę apie studijų procese taikomus studijų metodus, lūkesčius dèstytojų atžvilgiu ir nustatyti, kokios universiteto infrastruktūros jie tikisi.

Respondentai prisistate kaip Z kartos atstovai, pateikdami tokị autoportretą ir išskirdami tiek teigiamus, tiek ir neigiamus individualius, asmeninius bruožus: „esu lankstus, gebu prisitaikyti prie aplinkos; esu iniciatyvus, noriu büti lyderiu, esu komunikabilus, noriu mokytis visa gyvenima ir po bakalauro studiju noréčiau igyti dar viena specialybę; tačiau neplanuoju laiko, darbus atidedu paskutinei minutei, esu nemotyvuotas".

Tyrimo metu buvo siekiama sužinoti, kokie yra Z kartos studentų poreikiai universitete. Buvo nustatyta, kad bene didžiausias poreikis yra individualizuotu studijų metodų, nukreiptų i praktiką, taikymas. Studentai nurodė, kad juos domina individualus indèlis bendrame darbe, tai kaip dèlionès žaidimas, kuriame kiekvieno dalyvio indèlis padeda sudèlioti dèlionès piešini, t. y. sukurti visuminį vaizdą. Tyrimo dalyviai teigia, kad ,grupiniu rezultatu noréčiau siekti, atliekant individualias užduotis “; , "noréčiau, kad dèstytojas duotu užduoti grupei, bet su individualioms užduotimis, nes kai skaitai ir analizuoji vienas, gali kažko nesuprasti, o grupès kolegos gali padèti, paaiškinti“. Taip pat respondentai pabrěžè, kad juos labiau domintų studijų metodai, nukreipti ị praktiką ir teorinių žinių pritaikomumą: ,,tikejjausi daugiau praktikos ir mažiau teorijos, o realiai yra priešingai “, „neaišku, kaip teorija bus susieta su praktika“, „praktika yra svarbiau nei teorija “. Kaip labiausiai patrauklius studijų metodus ịvardijo „žodinius pristatymus; grupinị darbą; galimybę savarankiškai rinktis literatūra analizei; abipusę komunikacija su dèstytojais, ypač vertingos yra individualios destytojo konsultacijos".

Nenurodydami konkrečiu dęstytojų pavardžių, to tyrimo metu ir nebuvo siekiama, respondentai išreiškẻ nuomonę apie savo dèstytojus ir lūkesčius, kokius dèstytojus jie tikètųsi sutikti universitete. Pagal Z kartos studentų lūkesčius, dèstytojai turètų būti mėgstantys savo darbą ir motyvuoti dèstyti, išmanantys dèstymo metodikas, ne tik savo srities profesionalai, bet ir komunikabilūs, norintys bei mokantys bendrauti su studentais, noriai juos konsultuojantys, taip pat tolerantiški, empatiški ir pagarbūs studentų atžvilgiu.

Dèstančius dėstytojus studentai apibūdino labiau akcentuodami jų neigiamus bruožus. Anot Z kartos atstovų, dėstytojai yra „,nutole nuo studentu“, ,,jie ateina dèstyti, nes jiems pasiūlè, o ne todèl, kad nori dèstyti“, „patinka, kai dèstytojas daug konsultuoja, tačiau yra tokiu, kuriems studentai nerūpi“, „, dèstytojai neatsako i elektroninius laiškus “, „tikejjausi kitokios destymo metodikos, kai pavyzdžiui: destytojai skaito paskaitas, bet nebaigia analizuoti temos, vadinasi paskaitos tikslas buvo neigyvendintas “, „, dèstymo metodai pasenę, nenaudingi “. Be to, tiriamiesiems kartais ,neaišku, ar dalyko aprašas netinkamai parengtas, ar studiju programa negerai parengta, ar destytojas... ". Respondentai pastebejjo, kad studijų procese kartais taikomi ,atgyvenę studiju metodai, kai pavyzdžiui, dèstytojas skaito tekstus 
ir juos analizuoja. Norètusi patiems (studentams) rinktis literatūra pagal dèstytojo nurodyta tema“. Taip pat buvo pastebètas ,prastas dèstytojų metodinis pasirengimas “. Tiriamųų nuomone, ,svarbus yra dèstomo dalyko išmanymas, o ne dèstytojo išvaizda". Z kartos studentai yra kritiški dèstytojų atžvilgiu, tačiau patys yra itin jautrūs kritikai: ,, déstytoja pirma karta sutiktos studentés paklausé, kaip ji su tokio žemo lygio žiniomis galejo baigti mokykla“ “ arba ,per pirma užsiemima dèstytojas pareiškè, kad visi (visa grupe studentu) neišlaikys egzamino“.

Taip pat buvo siekiama sužinoti $\mathrm{Z}$ kartos poreikius universitete, t. y. kokia turètų būti studijų procesui pritaikyta universiteto infrastruktūra, ịranga ir t. t. Buvo nustatyta, kad respondentų lūkesčius atitiktų technologiškai aprūpintos universiteto auditorijos su daugiafunkciniais multimedijos projektoriais; studijos neịsivaizduojamos be laisvai, visoje universiteto teritorijoje prieinamo belaidžio interneto ryšio (Wi-Fi). Taip pat buvo išreikštas lūkestis, kad „,visa studijoms reikalinga medžiaga būtu patalpinta Moodle, Facebook'e, nes ,,informacijos studijoms ieškau internete, eLaba je, o ̣ biblioteka užsuku retai “. Z kartai taip pat svarbi studijoms pritaikyta fizinè aplinka, kuri turètų būti su ergonomiškais stalais, kẻdèmis ir apšvietimu: , kai kuriose auditorijose nepatogios kèdès ir stalai, sunku ilgesnị laika sèdèti “, ,, studiju erdvès turètu būti pritaikytos dirbti mažesnèmis ir didesnèmis grupelèmis “, , trūksta studiju erdvès mokymuisi, pavyzdžiui, nèra bibliotekos, kur nuejus būtu galima susikaupus pasimokyti, koridoriuose mokantis labai blaško kitu kalbos, o iki bibliotekos, esančios kitame fakultete, eiti toloka, ypač kai šalta". Galima teigti, kad tyrimo dalyviams yra svarbi visa universiteto infrastruktūra: formali fizinè erdvè, neformali ir virtuali.

\section{Išvados}

1. I dėstytoją orientuotose studijose pagrindinis veikejjas mokymo procese buvo dėstytojas, pasikeitus universitetinio mokslo paradigmai ši vaidmenị perèmé studentas ir studijos tapo orientuotos ị studentą. İ studentą orientuotų studijų procese kinta mokymo metodai paskaitų ir pratybų bei popaskaitiniu laikotarpiu. Paskaitų ir pratybų metu organizuojamos trumpos diskusijos, viktorinos ir vaidmenų žaidimai, rašomos refleksijos ir kt., o popaskaitiniu laikotarpiu vykdomi individualūs projektai, grupinès diskusijos, debatai ir kt.

2. Kinta ir studijų aplinka, t. y. infrastruktūra ir jos aprūpinimas šiuolaikinèmis technologijomis. Mokymosi erdvès pritaikomos paskaitoms, darbui mažomis grupėmis, darbui poromis, taip pat ir individualiam darbui. Taigi, auditorijos fizinè erdve taip pat darosi orientuota ị studentą.

3. Z kartos (1994-2012) socialinių medijų ir išmaniujų technologijų vartojimo ịūdžiai yra kur kas geresni nei ankstesnių kartų, todẻl jie vadinami „skaitmeniniais čiabuviais“. Išmanusis telefonas yra įrenginys, geriausiai patenkinantis jų poreikius virtualioje erdveje, naršant svarbiausiuose socialiniuose tinkluose Snapchat'e, Instagram‘e, Youtube'e. Iš prigimties jie mąsto ir veikia globaliai, turi 
verslo, karjeros gyslelę, yra aktyvistai ir agitatoriai, dideli svajotojai ir vizionieriai. Jų poreikiai yra kurti internetinius produktus, pramogas, jas tobulinti, o savo hobị paversti pagrindiniu pragyvenimo šaltiniu, neįdedant daug pastangų įgyti žinių verslo vadybos, psichologijos, švietimo, sistemų plètros, mokymų ir vystymo studijose.

4. Z kartos studentų nuomone, palanki universitetinių studijų aplinka būtų tada, jei studijų procesas būtų orientuotas ị individualizuotus studijų metodus, nukreiptus ị praktiką ir teorinių žinių pritaikomumą; jei dèstytojai būtų mėgstantys savo darbą, motyvuoti, išmanantys ịvairias dèstymo metodikas, jei būtų ne tik savo srities profesionalai, bet ir komunikabilūs, norintys bei mokantys pagarbiai bendrauti su studentais, noriai juos konsultuojantys, tolerantiški ir empatiški; jei universiteto auditorijos būtų modernios, technologiškai aprūpintos, ergonomiškai irengtos, visur prieinamas belaidžio interneto ryšys (Wi-Fi); jei visa studijoms reikalinga medžiaga būtų ịkelta ị Moodle, Facebook'ą, eLaba talpyklą.

\section{Literatūra}

1. Baužienė, Z., Daniels, N., Gołębiowski, A., Hughes, J., Kairienė, V., Knyvienè, I., Krawczak, M., Maj, G. P., Marinko, I., Marinko, J., Perkumienè, D., Reese, A. (2018). Pagalba déstytojams organizuojant i studenta orientuotas studijas. Prieiga internete: https://www.kaunokolegija.lt/kk_wp_content/uploads/2018/11/ tyrimas-ir-rezultatai.pdf

2. Cox, J. (2011). Kas yra ir kas nera i studenta orientuotas mokymas(is)? Prieiga internete: http://www.ects.cr.vu.lt/Files/File/cox.pdf

3. Galilei, G. (2016). Time for a new paradigm in education: student-centered learning. Student-Centered Learning SCL Toolkit. Prieiga internete: https:// www.esu-online.org/wp-content/uploads/2016/07/100814-SCL.pdf

4. Gilboy, M. B., Heinerichs, S., Pazzaglia, G. (2015). Enhancing Student Engagement Using the Flipped Classroom. Journal of Nutrition Education and Behavior. Volume 47, Issue 1, January-February, p. 109-114. Prieiga internete: https:// www.sciencedirect.com/science/article/abs/pii/S1499404614006381

5. Guščinskienè, J., Čiburienè, J. (2018). I studentą sutelktos studijos kaip karjeros kūrimo prielaida. Šiuolaikinès visuomeness ugdymo veiksniai $=$ The Factors of Education in Modern Society: scientific journal. Vilnius: Generolo Jono Žemaičio Lietuvos karo akademija. T. 3, p. 167-182.

6. Jeleniauskienè, E., Jucevičienè, P. (2015). Reconsidering University Educational Environment for the Learners of Generation Z. Social sciences. Vol. 2, No.88, p. 38-53.

7. Kleinschmit M. (2019). Generation $Z$ Characteristics: 5 Infographics on the Gen-Z Lifestyle. Prieiga internete: https://www.visioncritical.com/blog/generation-z-infographics

8. Leibtag, E. (2017). 8 Things to Look For in a Student-Centered Learning 
Environment. Prieiga internete: https://www.gettingsmart.com/2017/08/8-thingslook-student-centered-learning-environment/

9. Loveless, B. (2019). Developing a Student-centered Classroom. Prieiga internete: https://www.educationcorner.com/developing-a-student-centeredclassroom.html

10. Nessipbayeva, O., Egger, R. (2015). Comparative Study of Teaching Style and Infrastructure

11. Learning of Higher Education in Austria and Kazakhstan. Procedia - Social and Behavioral Sciences, 197, p. $1271-1277$

12. O'Neill, G., McMahon, T. (2005). Student-centered Learning: What Does It Mean for Students and Lecturers? Dublin. Prieiga internete: http://www. ucd.ie/teaching/t4media/Student\%20Centered\%20Learning\%20Article.pdf

13. Peilakauskaitè, K., Varanauskas, A. (2011). Studiju programu atnaujinimas: studentu vaidmuo diegiant ir tobulinant kompetencijomis grista ir $\underline{i}$ studentus orientuota studiju sistema. Vilnius: Vilniaus universitetas.

14. Powell, M. (2014). 5 Ways to Make Your Classroom Student-centered. Prieiga internete: http://www.edweek.org/tm/articles/2013/12/24/ctq_powell_ strengths.html

15. Ramoškienè, S. (2014). Z karta. Prieiga internete: http://psichika.eu/ blog/z-karta/

16. Raines Claire (2002). Managing Millennials. Prieiga internete: https:// www.academia.edu/13219793/Managing_Millennials

17. Robbins, S. (2007). Organizacinès elgsenos pagrindai. Kaunas: Poligrafija ir informatika.

18. Robinson, R., Reinhart, J. (2014). Digital Thinking and Mobile Teaching: Communicating, Collaborating, and Constructing in a Access Age. 1st. Edition. Prieiga internete: http://index-of.co.uk/IT-managment/digital-thinking-and-mobileteaching.pdf

19. Sajienè, L., Tamulienè, R. (2012). Studijų turinio kaita ị studentą orientuotų studijų paradigmoje: teorinis aspektas. Profesinis rengimas: tyrimai ir realijos. Nr. 23, p. 96-107.

20. Svarbiausi Bolonijos proceso dokumentai (2013) (Šorienė N. Red.) LR švietimo ir mokslo ministerijos, Švietimo aprūpinimo centras.

21. Targamadzè, V., Girdzijauskienè, S., Šimelionienè, A., Pečiuliauskienė P., Nauckūnaitè, Z. (2015). Naujoji (Z) karta - prarastoji ar dar neatrastoji? Naujosios (Z) kartos vaiko mokymosi procesu esminiu aspektu identifikavimas. Mokslo studija.

22. Weimer, M. (2013). Learner-centered Teaching: Five Key Changes to Practice. 2 ed. Prieiga internete: https://www.amazon.com/Learner-Centered-Teaching-Five-Changes-Practice/dp/1118119282\#reader_1118119282 


\title{
THE NEED FOR A FAVORABLE STUDY ENVIRONMENT. A CASE STUDY OF THE GENERATION Z
}

\author{
Assoc. Prof. Dr. Jūratė Guščinskienė \\ Aušra Kaminskaitė \\ General Jonas Žemaitis Military Academy of Lithuania
}

\section{Summary}

At the end of the twentieth century and the beginning of the twenty-first century, there was a shift in the paradigms of university science with the main focus switching from teacher to student. Student-centered studies are based on several principles (Guščinskienė, Čiburienè, 2018): teaching that requires constant reflection, no one-size-fits-all teaching method, and students possessing individual needs and interests. With the help of them, a choice in the study process emerges with the focus on students' knowledge; learners gain control over learning and students get empowered in the learning process (non-repetition of knowledge/information) by their collaboration with administration. Generational values, expectations, thinking, learning, and decision-making are different as well as academic needs. The Generation Z's social media and smart technology skills are significantly higher than those of previous generations. They seek to turn their hobby into a major source of livelihood and value personal rather than authoritybased experiences.

The research problem: although the paradigm of university science is in constant dynamics, Generation $\mathrm{Z}$ poses an exceptional demand for a favorable environment in higher education.

The research object: the attitude of the Generation $\mathrm{Z}$ towards the study environment in higher education.

The aim of the research: to discuss the specific needs of the Generation $\mathrm{Z}$ students and their views on the study environment after conceptualizing studentcentered studies and based on the results of the research completed in December 2018.

The research methods: the analysis of scientific literature, semi-structured interview, systematization, and interpretation.

The research identified the following:

1) In teacher-centered studies, the teacher was the key player in the teaching process, and as the paradigm of university science changed, the studies became student-centered. Obviously, the teaching methods also change during and after lectures and lessons. Moreover, they include more short discussions, quizzes, role-plays, reflections, post-lecture individual projects, group discussions, and 
debates.

2) As the study paradigms change, the infrastructure of the university and its supply with modern technologies are changing too. For example, learning spaces are adapted for lectures, small group work, pair work and individual work.

3) Generation Z (1994-2012) are experts in technology; a smartphone is prime for meeting their virtual space needs; they think globally, they create awesome products, they have a heart for business and career, they are activists, dreamers, visionaries who easily pursue business management, psychology, education, systems development, training and development in education.

4) The Generation $Z$ students would benefit from the university study environment if the study was mainly focused on individualized teaching methods and based on practice and applicability of theoretical knowledge; if lecturers loved their work, were motivated, knowledgeable about various teaching methodologies, and were not only professionals, but also communicative, willing to consult, and able to communicate respectfully with students, tolerant and empathetic; if the university infrastructure were technologically advanced, ergonomic, had wireless internet and was available everywhere; if the study material was accessible online.

Keywords: Generation Z, student-centered learning, expectations, values, individual and group work, teaching methods. 


\section{AUTORIŲ LYDRAŠTIS}

Autoriaus vardas, pavardė: Jūratė Guščinskienè

Mokslo laipsnis ir vardas: Socialinių mokslų daktarè, docentė

Darbo vieta ir pareigos: Generolo Jono Žemaičio Lietuvos karo akademijos Strateginio valdymo katedros docente

Autoriaus mokslinių interesų sritys: organizacijų sociologija, organizacijų komunikacija, aukštojo mokslo problemos ir kt.

Telefonas ir el. pašto adresas: jurate.guscinskiene@lka.lt

Autoriaus vardas, pavardè: Aušra Kaminskaitė

Mokslo laipsnis ir vardas: MSc

Darbo vieta ir pareigos: Generolo Jono Žemaičio Lietuvos karo akademijos Strateginio valdymo katedros lektore

Autoriaus mokslinių interesų sritys: karo sociologija; lyderystė; organizacinè elgsena; socializacijos procesas; profesijos; organizacinė kultūra

Telefonas ir el. pašto adresas: 862010764; ausra.kaminskaite@lka.lt

\section{AUTHORS' COVER LETTER}

Author's name and surname: Jūratė Guščinskienė

Academic degree and name: Doctor of Social Sciences

Workplace and position: Associate Professor, Department of Strategic Management, General Jonas Žemaitis Military Academy of Lithuania

Author's research interests: sociology of organizations, organizational communication, problems of higher education

Telephone and e-mail address: jurate.guscinskiene@lka.lt

Author's name and surname: Aušra Kaminskaitė

Academic degree and name: Master of Social Sciences

Workplace and position: Lecturer, Department of Strategic Management, General Jonas Žemaitis Military Academy of Lithuania

Author's research interests: military sociology, leadership, organizational behavior, socialization, professions, organizational culture

Telephone and e-mail address: +370 62010 764; ausra.kaminskaite@lka.lt 